\title{
Spatio-temporal distribution of spionids (Polychaeta-Spionidae) in an estuarine system in south-central Chile
}

\author{
Distribución espacio-temporal de los espiónidos (Polychaeta-Spionidae) en un sistema de \\ estuarios del centro sur de Chile
}

\section{MAURICIO DÍAZ-JARAMILLO ${ }^{1, *}$, PAMELA MUÑOZ², VÍCTOR DELGADO-BLAS ${ }^{3}$ \& CARLOS BERTRÁN² $^{2}$}

\author{
${ }^{1}$ Unidad de sistemas acuáticos, Centro EULA-Chile, Universidad de Concepción, Chile \\ ${ }^{2}$ Instituto de Zoología, Universidad Austral de Chile, Valdivia, Chile \\ ${ }^{3}$ División de Ciencias e Ingeniería, Universidad de Quintana Roo, México \\ * e-mail for correspondence: mauriciodiaz@udec.cl
}

\begin{abstract}
This study is based on the identification and distribution of spionid polychaetes in relation to abiotic characteristics of the environment at the mouth of the Valdivia-Tornagaleones estuary in south-central Chile. Four samplings were carried out in 2005, in which eight species were identified including Aquilaspio peruana, Boccardia polybranchia, Carazziella carrascoi, Dipolydora socialis, Minuspio patagonica, Rhynchospio glutaea, Scolelepis quinquedentata and Spiophanes sp. As it is typical of other estuaries in south central Chile, spionids were an important component of the macroinfauna of the Valdivia estuary. The distribution of the Spionidae family in the system showed higher species richness in the outer reach of the estuary but higher abundance (number of specimens) at the inner reach. The distributional pattern of the polychaetes did not vary throughout the year, exhibiting strong spatial zonation with three significantly different assemblages. Minuspio patagonica, A. peruana and C. carrascoi contributed to the similarity between these three groups, as well as to the formation of a general component in the macroinfauna. Sedimentological and depth variables, as well as sedimentary organic material were only marginally related to the distribution of spionids. Results showed that bottom salinity was the environmental variable responsible for spatial differentiation of spionids in the three groups, which permit to differentiate the outer-reach species from those in the internal area of the estuary. The significant contribution of spionids to the total component of macroinfauna in the studied area shows that these species are a significant component of the estuarine and transition areas in the southwest Pacific coast.
\end{abstract}

Key words: Polychaeta, Spionidae, distribution, estuary, salinity, sediments, Chile.

\section{RESUMEN}

El estudio se desarrolla en base a la identificación y distribución de Spionidae y su relación con las características abióticas del medio, en la desembocadura del sistema estuarial Valdivia-Tornagaleones (Chile). Se muestrearon cuatro periodos en 2005, identificándose ocho especies, Aquilaspio peruana, Boccardia polybranchia, Carazziella carrascoi, Dipolydora socialis, Minuspio patagonica, Rhynchospio glutaea, Scolelepis quinquedentata y Spiophanes sp. Como es típico en otros estuarios del centro sur de Chile, los espiónidos fueron un componente importante de la macroinfauna del estuario Valdivia. La distribución de la familia Spionidae en el sistema estudiado mostró una mayor riqueza de especies en la zona exterior del estuario, pero altas abundancias (número de especies) en las zonas interiores. El patrón distribucional no varió a lo largo del año, pero sí mostró una fuerte zonación espacial, con tres grupos significativamente diferentes. Destacó la contribución de M. patagonica, A. peruana y C. carrascoi en la similaridad de cada uno de estos grupos y de igual forma dentro del componente general de la macroinfauna. Las variables sedimentológicas y profundidad como también la contribución de la materia orgánica fueron solamente relacionadas marginalmente con la distribución de esta familia. Los resultados mostraron que la variable ambiental responsable en diferenciación espacial de los espiónidos en los tres grupos, fue la salinidad de fondo permitiendo diferenciar el grupo más externo con los ubicados al interior de la zona de estudio. La importante contribución de los espiónidos en el componente total de la macroinfauna de la zona de estudio, permiten establecer que especies de esta familia representan un componente importante de zonas estuarinas y de transición de las costas del pacífico sudoriental.

Palabras clave: Polychaeta, Spionidae, distribución, estuario, salinidad, sedimentos, Chile. 


\section{INTRODUCTION}

The Spionidae are one of the most abundant and diversified families of Polychaeta that inhabit sublittoral soft bottoms of bays and estuaries (Blake 1996). Spionids have probably achieved evolutionary success and dominance in coastal ecosystems due to the great plasticity in their particle capture methods for feeding and/or construction of tubes (Dauer et al. 1981), as well as for their diverse mechanisms for reproduction and development (Blake \& Arnofsky 1999). In mud and sand environments, spionids help to stabilize and compact the surface layers of soft bottoms (Blake 1996), often forming extensive assemblages in areas with high contents of organic matter (Pearson \& Rosemberg 1978).

As all other macroinfauna of soft bottoms, the distribution and population variation within spionid species, have been attributed to: (i) reproductive events and interactions between species (Whitlatch \& Zajac 1985, Bolam \& Fernández 2002), (ii) availability in food supply (Beukema \& Cadeé 1986), (iii) natural or anthropogenic disturbance (Levin 1984), (iv) sedimentological characteristics of the habitat (Snelgrove \& Butman 1994), and (v) seasonal and espatial variations in physical factors, such as salinity and temperature (Holland et al. 1987).

The taxonomy of spionids has been most extensively studied compared to other families (Johnson 1984). Nevertheless, there are still numerous species considered to be cosmopolitan, or having wide distribution, which can be considered a misinterpretation due to the lack of rigorous taxonomic studies and the absence of keys to identify species. However, this does not seem to be a problem in Chilean coastal regions since there is a large number of taxonomic and distributional researches (Hartmann 1953, HartmannSchröder 1962, 1965, Carrasco 1974, Blake 1979, 1983, Moreno et al. 2002, Sato-Okoshi \& Takatsuka 2001, Cañete et al. 2004), and studies on reproductive and larval development (Carrasco 1976, Radashewsky et al. 2006). In addition, important observations have been made about the relations between polychaetes and local sedimentary characteristics (Rozbaczylo \& Salgado 1993, Quiroga et al. 1999).
The south-central coast of Chile has a number of microtidal estuaries between $38^{\circ}$ and $41{ }^{\circ} \mathrm{S}$, with mixed or exclusively riverine hydraulic regimes. Many of these have been studied with regard to their macrobenthic intertidal or subtidal community structure (Bertrán 1984, 1989, Bravo 1984, Turner 1984, Richter 1985, Jaramillo et al. 1984, 1985 a, 1985 b, 2001, Low 1993, Quijón \& Jaramillo 1993, Quijón et al. 1996, Bertrán et al. 2001). Nevertheless, most studies have been carried out in estuaries with small coastal drainage basins, generally describing the existing fauna. The boundaries of these environments have been traditionally defined according to physico-chemical variables, which have a high variability due to tide and freshwater supply changes, rather than to the fauna that they support. Therefore, certain species may eventually be used as indicators to determine more accurately the boundaries of these environments. Given the extensive knowledge, availability, and wide distribution of spionids in soft bottoms, both in marine and estuarine ecosystems, this study of spatio-temporal variation of spionids and its relationship with important environmental variables provide an approach to define natural limits between these transition areas and marine environments.

The objective of the present study was to identify and describe species of subtidal Spionidae in the Valdivia-Tornagaleones estuarine system, which is one of the major systems on the Chilean coast and, unlike other large estuarine systems, such as the Biobío river, the Valdivia-Tornagaleones estuary discharge regimes are mostly caused by rain with a minor seasonal variability (Bertrán et al. 2001). Results of the study are expected to provide information about the distribution and abundance of spionids across salinity and other gradients in these transitional zones. It is expected that spionids will represent a significant part of the entire benthic macrofauna in the estuary and that their spatio-temporal distribution will be correlated to the strong natural gradients founded in the estuary, in which we expect to find strong variations between marine and estuarine components of the spionid assemblage. 


\section{MATERIAL AND METHODS}

Study area

The Valdivia-Tornagaleones estuarine system is located in south-central Chile $\left(39^{\circ} 49^{\prime} \mathrm{S}\right.$, $73^{\circ} 18^{\prime} \mathrm{W}$ ) and includes the estuaries of the Valdivia and Tornagaleones rivers, the San Juan inlet, and Corral Bay (Fig. 1). This system is of neotectonic origin, and its estuaries are classified as "positive microtidal" with partially mixed water circulation (Pino et al. 1994). The depths of the estuary range from 3 to $9 \mathrm{~m}$, with maximum depths to $11 \mathrm{~m}$ in some inner reaches (Poblete \& Deppe 1978) and 5 to $14 \mathrm{~m}$ in its exterior zones (Arcos et al. 2002). The sediments in the estuary are composed mainly of sands and muddy sands (Low 1993). The tidal regime is semi-diurnal with a mean tidal range of $\pm 1.48 \mathrm{~m}$ (Pino et al. 1994). The maximum salinities (33-34 psu) encountered in the deeper waters occur in Corral Bay during the summer and fall months, while the lowest salinity values $(0-8 \mathrm{psu})$ occur in the inner regions of the Valdivia and Tornagaleones estuary during winter and spring. The temperature in the deep waters reaches a maximum of $17{ }^{\circ} \mathrm{C}$ in the summer months and a minimum of $8.8^{\circ} \mathrm{C}$ in the winter (Poblete \&
Deppe 1978, Pino et al. 1994, M. Pino personal communication).

\section{Sampling procedures}

Twelve stations were sampled once each during the months of March, June, September, and December 2005 (Fig.1). Geographic positions in the field were determined using a KODEN KGP-910A global positioning system with a precision of 0.001 '. Five replicate samples were haphazardly collected at each station for analysis of the benthic fauna using an Emery dredge $\left(0.025 \mathrm{~m}^{2}\right)$. Each sample was screened to $0.5 \mathrm{~mm}$, and the organisms collected were fixed in $10 \%$ seawater-formalin for subsequent observation and counting using a stereoscopic microscope, and were then preserved in $70 \%$ ethanol. Identification of the spionids was carried out using the publications of HartmanSchröder (1965), and Blake (1979, 1983, 1996). Three replicate subsamples from each station were analyzed for sediment grain size using a graded series of geological screens, quantifying the fractions of gravel $(>2 \mathrm{~mm})$, sand-gravel $(0.063-2 \mathrm{~mm})$, and mud $(<0.063 \mathrm{~mm}$ ) $)$ (Folk 1974). Total organic matter content was determined by the ash free dry weight (AFDW) method by ashing the samples in a furnace for 4
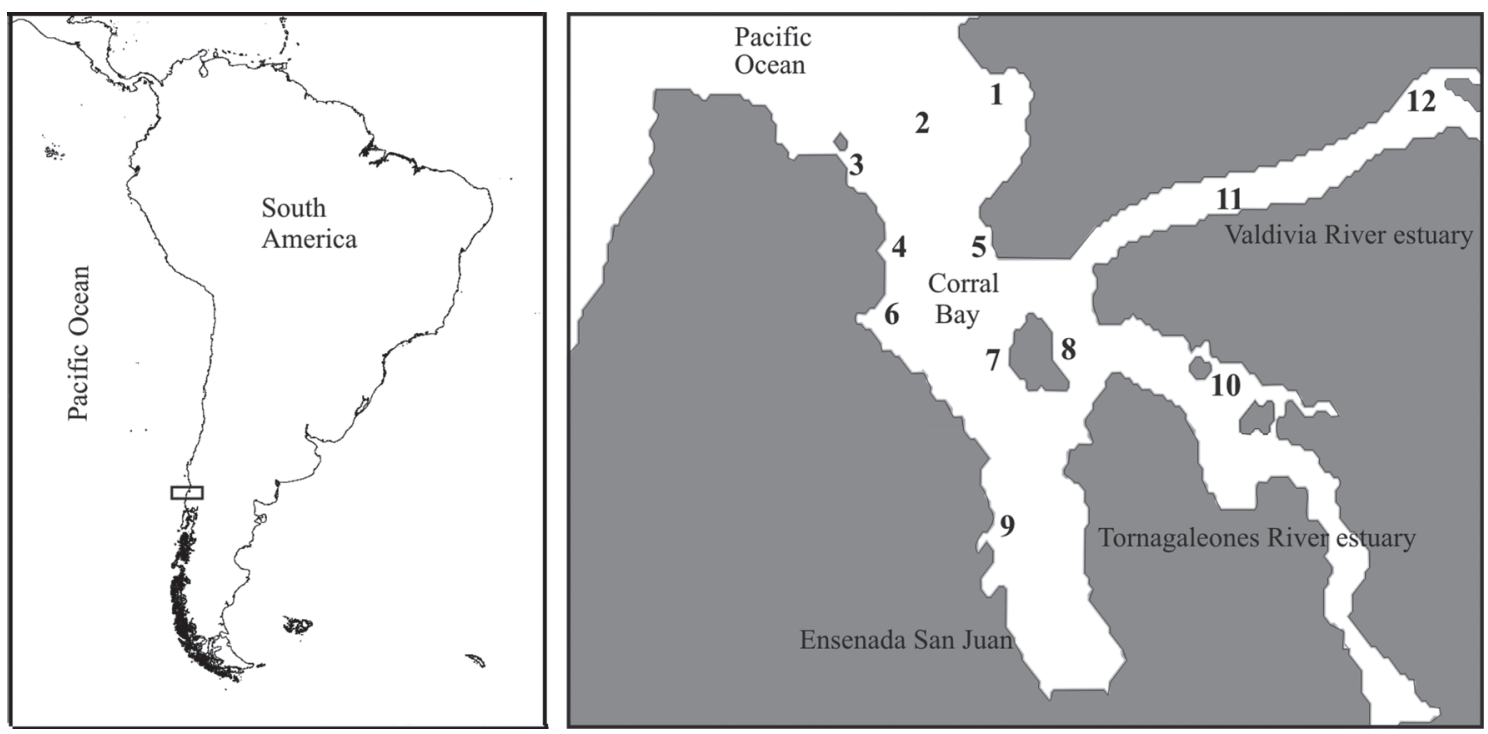

Fig. 1: Map of the sampling area. The location of Valdivia and Tornagaleones river estuaries are indicated by the rectangle. Numbers indicate the approximate location of sampling sites.

Mapa del área de estudio. El rectángulo indica la ubicación de los estuarios Valdivia y Tornagaleones. Los números indican la ubicación aproximada de los sitios de muestreo. 
$\mathrm{h}$ at $550{ }^{\circ} \mathrm{C}$. Particle size determinations were carried out using a modified Emery method (Emery 1938, Gibbs et al. 1971). Estimations of comparative salinities among our sampling stations were extrapolated from historical data from the studied area obtained during seasonal periods similar to those of our sampling. This approximation is justified by the daily wide variability of this parameter in the studied area, and it was not possible to determine it on site due to difference in time of sampling at each location. (Poblete \& Deppe 1978, Pino et al. 1994, M. Pino personal communication).

\section{Data analysis}

Each station within the study area was described by its comparative percentage make up of sand, gravel, mud, and organic matter, and also by mean particle size, depth, and salinity. The abiotic variables were normalized and analyzed using principal component analysis (PCA), applied to all the sampling stations during the four periods of the year sampled.

The overall macrobenthic structure and that of the spionid fauna at each sampling station, were analyzed using univariate community parameters, such as the number of individuals (n), species richness (S), and Shannon-Wiener diversity index $\left(\mathrm{H}^{\prime} \log _{\mathrm{e}}\right)$. Analysis of variance (ANOVA) was applied to determine the significant differences between these parameters between sampling stations, following confirmation of normality and homocedasticity of the variances of residuals using KolmogorovSmirnov likelihood and Bartlett tests, respectively (Sokal \& Rohlf 1995).

The comparison of patterns of abundance of spionids among sampling sites, as well as their seasonal variation, were analyzed using a similarity analysis test (ANOSIM) (Clarke \& Warwick 1994). A multidimensional nonparametric scaling ordination (MDS) was used to visualize faunistic similarities of the different taxa of spionids from the sampling sites, using the Bray-Curtis species similarity index, and grouped using a previously applied cluster analysis.

The spionid species responsible for generating similarities among the different groups, and within the overall macrofaunal component were determined using a similarity percentages routine (SIMPER, Clarke \&
Ainsworth 1993). The environmental variables, as well as the depth and structure of the spionid fauna, were analyzed using Spearman coefficient $\mathrm{p}_{\mathrm{w}}$ (BIO-ENV analysis), which selects a variable or combination of variables which best represents the local community structure (Clarke \& Warwick 1994). A LINKTREE analysis was applied for the determination of which abiotic variables represented the greatest differences (SIMPROF test) among the different stations in different sampling seasons (Clarke \& Gorley 2005). All analyses were carried out using PRIMER V.6 software developed at the Plymouth Marine Laboratory (Clarke \& Gorley 2005).

\section{RESULTS}

\section{Environmental variables}

Sand was the most common sedimentary component range between 56-96\% at all sampling stations during the study period, followed by the mud fraction $(2-55 \%)$, with the least important being the gravel fraction $(0-$ $4 \%$ ) (Table 1). The principal components analysis (PCA) showed a clear separation between the interior and middle sampling stations on the one hand and the stations located in outer reaches of the estuary. This separation was mostly due to the gradient in salinity and depth, both of which increased markedly with distance out off the estuary (Fig. 2). Also, a group of stations was characterized by a greater percentage of sand together with a greater heterogeneity in particle size; these stations were relatively more exposed to physical disturbance (Fig. 2). Station 9 (Fig. 1) had lower mean particle size during at all sampling periods, with larger percentages of mud and organic matter (Fig. 2, Table 1).

\section{Spionid faunal composition}

Eight species of spionid polychaetes were collected during the year, including Boccardia polybranchia (Haswell, 1885), Carazziella carrascoi (Blake, 1979), Dipolydora socialis (Schmarda, 1861), Minuspio patagonica (Augener, 1923), Aquilaspio peruana (Hartmann-Schröder, 1962), Rhynchospio glutaea (Ehlers, 1897), Scolelepis 
quinquedentata (Hartmann-Schröder, 1965) and Spiophanes sp., T species similar to $S$. bombyx (Claparède, 1870) but differing in certain morphological aspects and; its identification remains to be confirmed (Díaz \& Delgado-Blas unpublished results). The list of spionids contains cosmopolitan species such as $D$. socialis, $R$. glutaea and B. polybranchia (Blake 1996). Although the type locality for $B$. polybranchia is in Chile, it has been reported in other parts of the world. The most abundant species during the study was $M$. patagonica (1892 ind $\mathrm{m}^{-2}$ ), which was distributed in both the interior and intermediate areas of the estuary, and showed maximum abundances in March and December (Fig. 3). The second most abundant species was A. peruana (230 ind $\mathrm{m}^{-2}$ ), which was also most abundant in March and December (Fig. 3), but, in contrast to the M. patagonica, was distributed in the outer reaches of the estuary. The third species in relative abundance was $R$. glutaea (208 ind $\mathrm{m}^{-2}$ ), which was mostly distributed in the external zone, with highest abundances in September and December (Fig. $3)$. D. socialis was present with high densities in the outer and intermediate areas $\left(143\right.$ ind $\left.\mathrm{m}^{-2}\right)$, particularly in March. Spiophanes sp. was present at considerable densities in the outer zones in December (108 ind $\left.\mathrm{m}^{-2}\right)$. C. carrascoi also showed its greatest densities in December, in the external and intermediate zones of the Bay (101 ind $\mathrm{m}^{-2}$ ) (Fig. 3). B. polybranchia was present in December at a high density (231 ind $\mathrm{m}^{-2}$ ) only at station 8 , located in the intermediate zone; while densities at other stations and other seasons this species was rare in terms of abundance, but was very widely distributed. Similarly, $S$. quinquedentata was present in low abundance (1-5 ind $\mathrm{m}^{-2}$ ) and widely distributed over the study area.

\section{Faunal univariate analysis}

The number of individuals n, species richness $S$ and species diversity $H^{\prime}$, for each station showed similar patterns both for the total macrofauna and for the spionid species as a group (Fig. 4). The number of individuals (n) was greatest at stations 10 and 11 , where the composition of the spionid fauna was significantly different from the spionids of the other stations (Fig. 4). The number of species $(S)$ and the diversity index $\left(H^{\prime}\right)$ had comparatively greater values at stations located within the estuary (1-7), lower values were found at stations 10,11 and 12 located in the interior of the Valdivia river portion of the estuary (Fig. 4).

\section{TABLE 1}

Means \pm SD $(n=12)$ of environmental parameters of each of the 12 sampling locations, from March to December 2005. Asterisks indicate relative parameters extracted from historical data

Promedios \pm DE $(n=12)$ de parámetros ambientales en cada uno de los 12 sitios muestreados, desde marzo a diciembre de 2005. Asteríscos indican parámetros relativos extraídos de datos históricos

\begin{tabular}{lcccccccc}
\hline Site & $\begin{array}{c}\text { Distance } \\
\text { to mouth }(\mathrm{km})\end{array}$ & \% Grab & \% Sand & \% Mud & $\begin{array}{c}\text { \% Organic } \\
\text { matter }\end{array}$ & $\begin{array}{c}\text { Mean grain } \\
\text { size }(\Phi)\end{array}$ & Depth (Z) & Salinity (psu)* \\
\hline 1 & 0.39 & $1.81 \pm 2.37$ & $94.09 \pm 2.44$ & $3.53 \pm 2.72$ & $1.79 \pm 0.34$ & $1.89 \pm 0.11$ & $6.25 \pm 0.84$ & $27.75 \pm 3.77$ \\
2 & 0.13 & $0.00 \pm 0.00$ & $91.17 \pm 3.14$ & $6.59 \pm 2.32$ & $3.15 \pm 2.00$ & $2.23 \pm 0.13$ & $16.00 \pm 1.41$ & $27.75 \pm 3.77$ \\
3 & 0.32 & $3.79 \pm 4.24$ & $83.91 \pm 7.03$ & $11.18 \pm 7.80$ & $3.05 \pm 1.23$ & $1.75 \pm 0.16$ & $9.63 \pm 0.68$ & $27.75 \pm 3.77$ \\
4 & 2.58 & $0.43 \pm 0.61$ & $56.48 \pm 19.84$ & $38.20 \pm 18.90$ & $7.64 \pm 3.00$ & $1.95 \pm 0.21$ & $9.13 \pm 1.22$ & $21.75 \pm 2.36$ \\
5 & 2.79 & $0.61 \pm 0.50$ & $92.22 \pm 4.86$ & $4.36 \pm 3.63$ & $3.93 \pm 3.72$ & $1.73 \pm 0.40$ & $5.68 \pm 0.05$ & $21.75 \pm 2.36$ \\
6 & 3.72 & $0.85 \pm 0.77$ & $73.49 \pm 11.24$ & $23.26 \pm 10.32$ & $4.59 \pm 1.88$ & $1.57 \pm 0.50$ & $11.83 \pm 0.35$ & $21.75 \pm 2.36$ \\
7 & 4.87 & $0.22 \pm 0.18$ & $96.93 \pm 1.59$ & $2.47 \pm 1.42$ & $1.55 \pm 0.34$ & $1.56 \pm 0.23$ & $6.88 \pm 0.22$ & $21.75 \pm 2.36$ \\
8 & 5.22 & $0.19 \pm 0.21$ & $83.18 \pm 8.94$ & $14.78 \pm 8.95$ & $6.26 \pm 4.46$ & $1.96 \pm 0.29$ & $3.88 \pm 0.38$ & $16.00 \pm 3.37$ \\
9 & 7.25 & $0.17 \pm 0.04$ & $38.01 \pm 3.80$ & $55.50 \pm 5.37$ & $10.13 \pm 2.40$ & $2.28 \pm 0.16$ & $4.60 \pm 0.24$ & $16.00 \pm 3.37$ \\
10 & 8.14 & $1.30 \pm 2.30$ & $89.24 \pm 6.39$ & $7.91 \pm 5.40$ & $3.92 \pm 1.29$ & $2.10 \pm 0.14$ & $6.53 \pm 0.93$ & $5.25 \pm 2.06$ \\
11 & 7.03 & $4.16 \pm 4.34$ & $79.95 \pm 8.17$ & $14.14 \pm 7.16$ & $3.58 \pm 1.10$ & $1.95 \pm 0.32$ & $3.05 \pm 0.64$ & $5.25 \pm 2.06$ \\
12 & 11.81 & $0.32 \pm 0.46$ & $88.47 \pm 11.33$ & $9.24 \pm 9.72$ & $2.75 \pm 1.79$ & $1.62 \pm 0.62$ & $5.90 \pm 0.48$ & $5.25 \pm 2.06$ \\
\hline
\end{tabular}

\footnotetext{
* Relative salinity extracts from historical data
} 


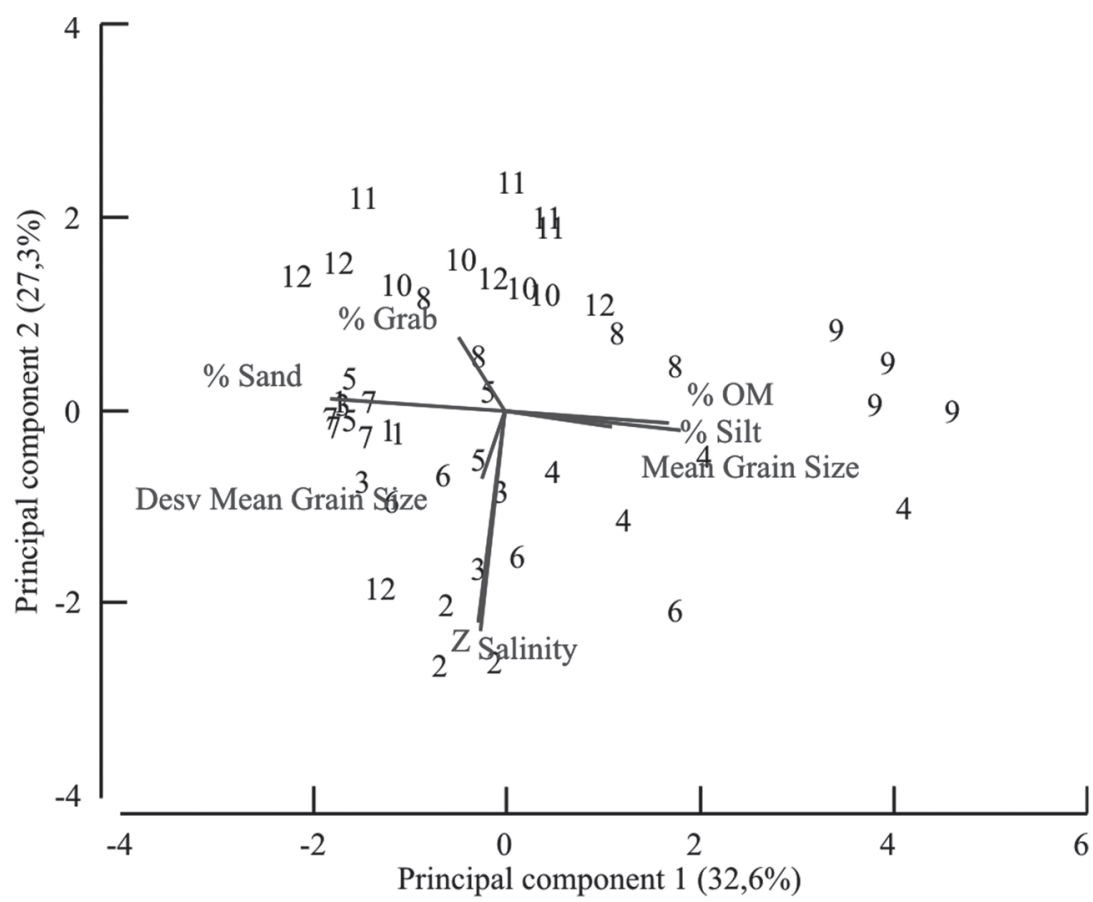

Fig. 2: Analysis of abiotic variables in the Valdivia and Tornagaleones river estuaries sampling sites by principal component analysis (PCA). Numbers indicate sampling sites in different seasons. The percentage of variability explained by the principal axis it is showed.

Análisis de las variables abióticas en los sitios de muestreo de los estuarios de Valdivia y Tornagaleones mediante el análisis de componentes principales (PCA). Los números indican los sitios muestreados en las diferentes estaciones del año. Se indica el porcentaje de variabilidad explica por cada eje principal.

\section{Faunal multivariate analysis}

There was no significant difference in spionid fauna among sampling stations due to season of sampling (2-way ANOSIM, R overall = - 0.017 , $\mathrm{P}>0.05)$, although the composition of the spionids was significantly different among the groups of sampling stations (2-way ANOSIM, $\mathrm{R}$ global $=0.771, \mathrm{P}<0.05)$.

When averaging across sampling periods, MDS ordination showed three significantly different groups of spionids (Fig. 5, Table 2). The first grouping was conformed by species from stations in the outer reaches of the estuarine system (stations 1-7). The second group is represented by stations located mainly in the intermediate zone of the study area (stations 8 and 9) and a third group was represented by the samples collected in the interior zone of the estuarine system at stations 10, 11 and 12 (Fig. 5).

Species with highest percentage of contribution to dissimilarty (SIMPER) in each of the groups were A. peruana wich contributed to greatest dissimilarity $(22.34 \%)$ between the most external group (Group 1) and intermediate group (Group 2), and $C$. Carrascoi, wich was responsible the highest degree of dissimilarity $(21.40 \%)$ between Group 2 and Group 1 (Table 3). For the group of samples collected from the interior region of the estuary (Group 3), M. patagonica, made the major contribution to dissimilarity of Group 1 (47.92\%), while A. peruana contributed 21.32 $\%$ to the dissimilarity between Group 1 and Group 3 (Table 3). M. patagonica contributed $50.09 \%$ to the dissimilarity between Group 1 and Group 2 (intermediate site), while $C$. carrascoi, contributed $30.08 \%$ of the dissimilarity between Group 2 and the group located within the interior of the estuary (Table $3)$. Among the species of benthic macrofauna that contributed $>65 \%$ of the similarity (SIMPER), the contribution from five species of spionids was notable as an overall contribution from the macrofauna (Table $4)$. The contributions of the spionids $C$. carrascoi (14.17\%) and M. patagonica (37.67 
$\%$ ) were notable in comparisons of the groups from the intermediate and interior areas of the estuaries (Table 4).

Table 5 shows the result of the BIO-ENV analysis showing the two maximum values for the range coefficient of the Spearman correlation. For the best combinations of one, two and three variables, the coefficient $\left(\rho_{\mathrm{w}}\right)$ has values near one when good correlation exists and near zero when there is little or no correlation. The analysis showed that from a total of five sedimentary variables (\% gravel, $\%$ mud, $\%$ sand, mean particle size, and $\%$ organic matter, plus bottom salinity and depth, salinity produced the highest values of $\rho_{\mathrm{w}}$. The second best combination of variables, defining the distribution of Spionidae in the studied area, was $\%$ sand and salinity, and the third best combination was \% sand, depth and salinity.
The contribution of the organic matter (OM) was not significant in the distribution of Spionidae. The results of the main groups with significant differences obtained through Linktree analysis using environmental variables in different sampling seasons, initially showed two groups with significant differences (SIMPROF, $\mathrm{r}=0.83, \mathrm{P}$ $<0.05$ ) having the group of stations in outer sectors of the estuary (A) and most stations from the middle and inner sectors of the studied area (B) with salinity being the essential factor for differentiation between these groups (Table 5). Station 9 was separated from other stations (B-C) during most of the study, mainly due to the high levels of organic matter and low percentage of sand (Table 5). The separation among other groups of stations located at the intermediate and interior zones of the estuary was based on slight variations in salinity and organic matter content (Table 5).

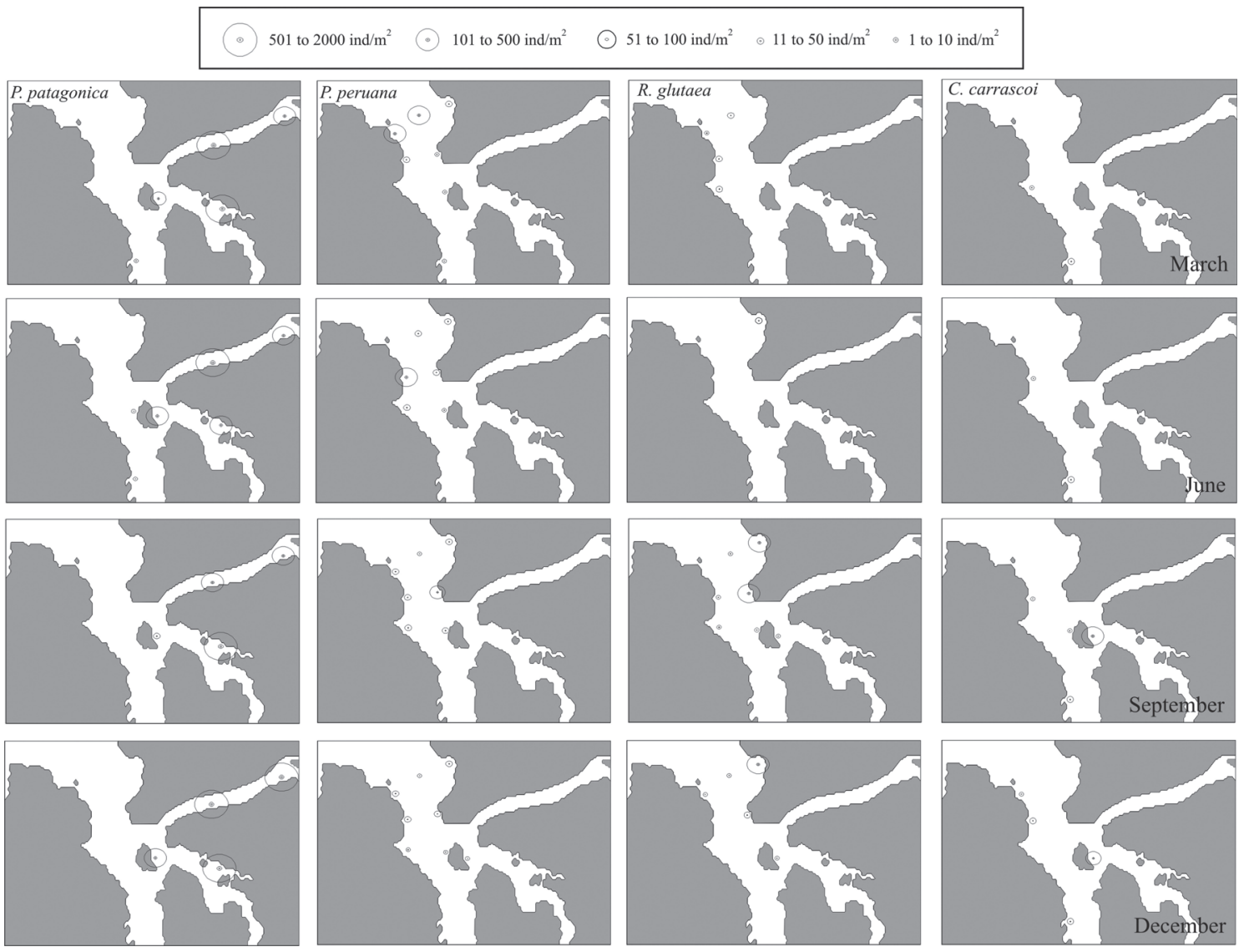

Fig. 3: Spatial representation of seasonal average density (ind $\mathrm{m}^{-2}$ ) of spionids polychaetes from Valdivia and Tornagaleones river estuaries.

Representación espacial del promedio de densidades estacionales de poliquetos espiónidos (ind $\mathrm{m}^{-2}$ ) en los estuarios de Valdivia y Tornagaleones. 
(A)

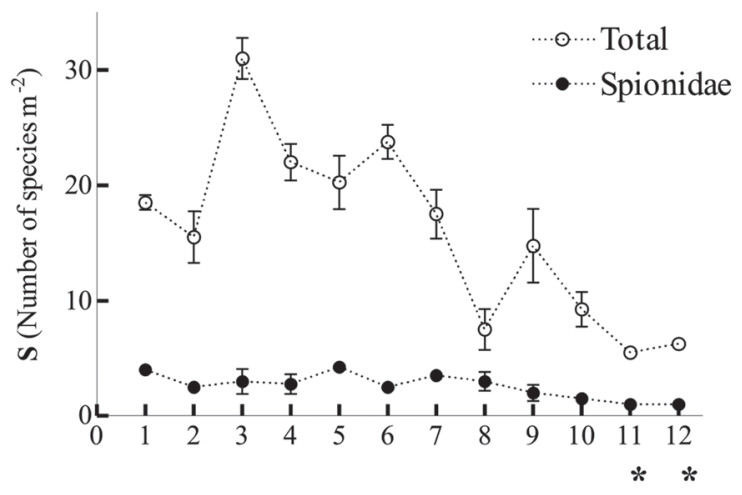

(B)

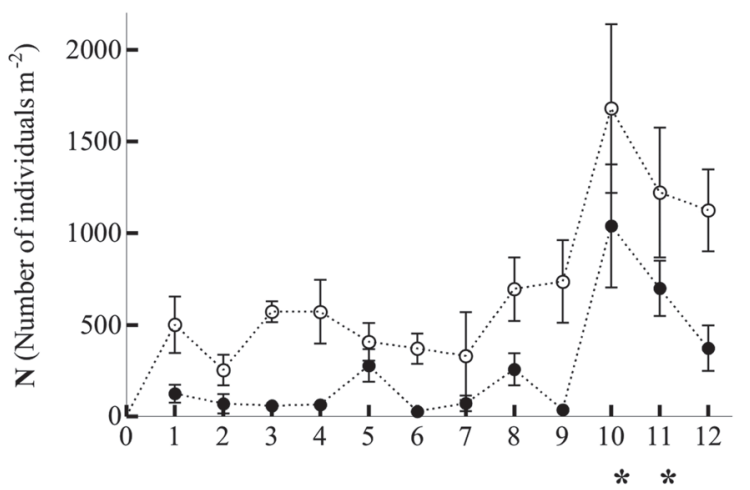

(C)

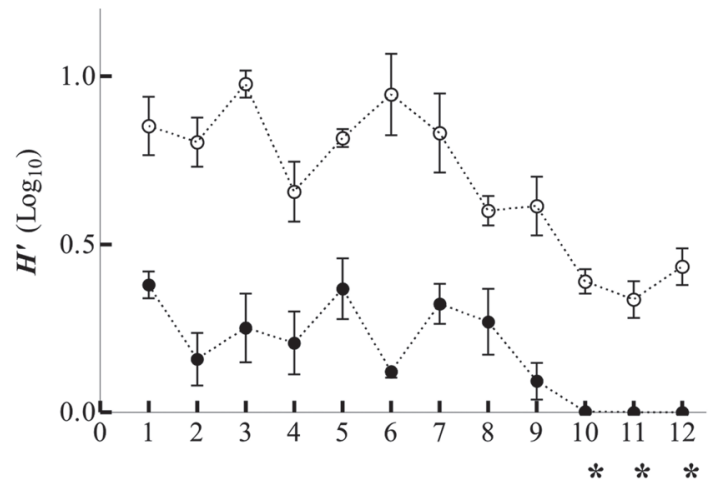

Fig. 4: Number of species (A), number of individuals (B) and Species diversity index (C) of the total macrobenthic fauna and spionid polychaetes at sampling sites from Valdivia and Tornagaleones river estuaries. Asterisks indicate statistically significant differences between means $(\mathrm{P}<0.05)$ after using ANOVA.

Número de especies (A), número de individuos (B) e índice de diversidad de especies (C) de la fauna macrobentónica total y de los poliquetos espiónidos en los sitios de muestreo de los estuarios de Valdivia y Tornagaleones. Los asteriscos indican diferencias significativas entre medias $(\mathrm{P}<0,05)$ después de realizar ANOVA. 


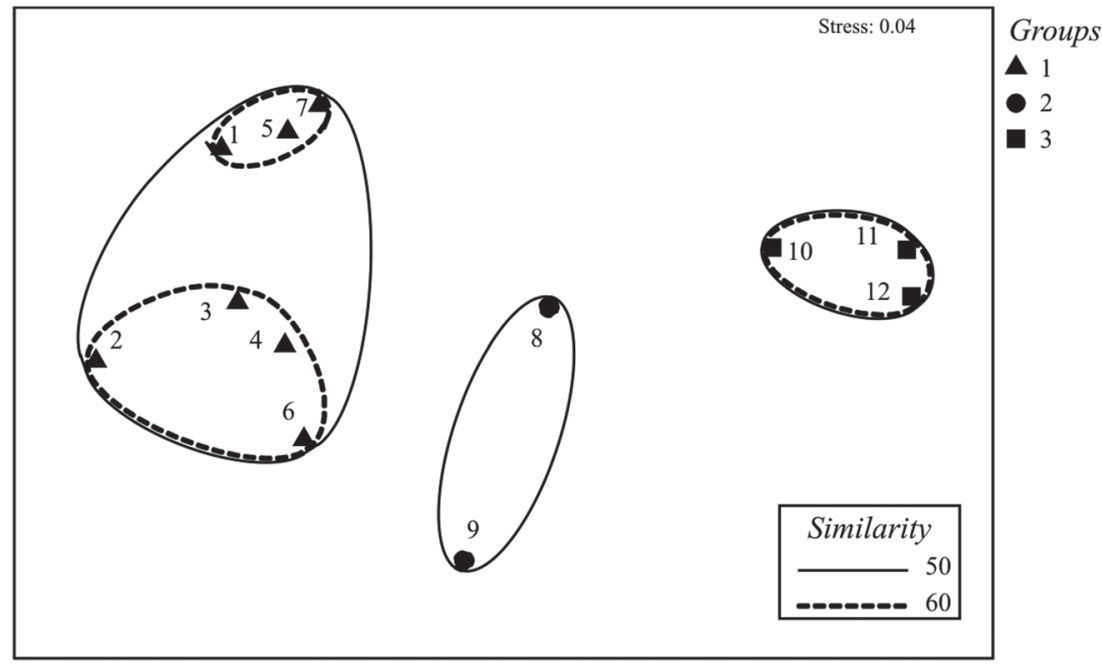

Fig. 5: Multidimensional scaling (MDS) ordination plot of the spionids polychaetes cluster groups. Numbers indicate each sampling site using average values of abundance in different periods of the year $(n=4)$ from Valdivia and Tornagaleones river estuaries.

Gráfico de escalamiento multidimensional (MDS) de grupos de cluster de poliquetos espiónidos. Números indican cada sitio de muestreo utilizando valores promedio de abundancia en los diferentes periodos del año $(n=4)$ de los estuarios de Valdivia y Tornagaleones.

\section{TABLE 2}

$\mathrm{R}$ values and significance levels $(\mathrm{P})$ from ANOSIM 1-way analysis of similarity $(\mathrm{P}<0$. $05)$ for differences between cluster groups of spionids community structure

Valores de R y niveles de significancia (P de ANOSIM análisis de similaridad de 1 -vía $(\mathrm{P}<0,05)$ para diferencias entre grupos de cluster de la estructura comunitaria de los espiónidos

\begin{tabular}{lcc}
\hline Cluster group & r-value & $\mathrm{P}$-value \\
\hline $1 \& 2$ & 0.811 & $\mathrm{P} \leq 0.001$ \\
$1 \& 3$ & 0.965 & $\mathrm{P} \leq 0.001$ \\
$2 \& 3$ & 0.672 & $\mathrm{P} \leq 0.001$ \\
Global & 0.836 & $\mathrm{P} \leq 0.001$ \\
\hline
\end{tabular}

\section{DISCUSSION}

The number of species of spionid polychaetes in the studied zone were about a third of the 30 species described for the coast of Chile (Blake 1983, Lancellotti \& Vásquez 2000, Sato-Okoshi \& Takatsuka 2001, Cañete et al. 2004). This number of spionid species is similar to the one found in the coast near Valparaíso and Concepción (Carrasco 1974, Rozbaczylo \& Salgado 1993), and relatively higher than the number found by studies on the northern coast of
Chile (Quiroga et al. 1999, Moreno et al. 2002), in agreement with the idea of lower diversity of polychaetes with decreasing in latitude (Lancellotti \& Vásquez 2000, Hernández et al. 2005). Nevertheless, it is important to determine whether differences in the richness and abundance of species found among these studies reflect a true pattern or whether they are related to differences in is related to differences in sampling effort among studies. Our finding of C. carrascoi represents a new record for this region, since it was only reported for the coast near Concepción (Blake 1979).

The sediment texture values were in agreement with those previously described for southern Chile, where sand was the major component of subtidal sediments, followed by the mud fraction (Jaramillo et al. 1985b, Richter 1985, Bertrán 1989, Low 1993). The predominance of sand fraction in these environments is mainly related to the estuarine dynamics, i.e., bottom currents considerably impede the deposition of finely particulate matter (Bertrán et al. 2001). Similarly, the small seasonal variation in sedimentological characteristics of most sampling stations suggested relatively stable bottom conditions in this type of estuary in comparison with estuaries located in the northernmost portions 
of southern Chile, were hydrologic flows vary widely in relation to seasonal changes (Bertrán et al. 2001).

Observations of the spionid group, as well as of the entire benthic community, showed a larger number of species in small amounts at the outer (oceanic) reaches of the estuary, and few species in great abundance in the inner reaches, in agreement with studies in other estuaries (Ieno \& Bastida 1998, Costanza et al. 1993). High densities of M. patagonica, were previously noted throughout the year in the inner estuarine system of the Lingue River estuary (Bravo 1984, Richter 1985) and the Queule River (Jaramillo et al. 1985b, Quijón \& Jaramillo 1996, Jaramillo et al. 2001). Thus, $M$.

TABLE 3

Percentage of contribution of spionids species in the average Bray-Curtis dissimilarity between the three spionids polychaetes groups from the 12 sites (SIMPER)

Porcentaje de contribución de las especies de espiónidos en los promedios de disimilaridad de Bray-Curtis entre los 3 grupos de poliquetos espiónidos en los 12 sitios (SIMPER)

\begin{tabular}{|c|c|c|c|c|c|c|c|c|}
\hline \multirow[t]{2}{*}{ Species } & \multicolumn{2}{|c|}{ Groups $1 \& 2$} & \multirow[t]{2}{*}{ Species } & \multicolumn{2}{|c|}{ Groups $1 \& 3$} & \multirow[t]{2}{*}{ Species } & \multicolumn{2}{|c|}{ Groups $2 \& 3$} \\
\hline & $\begin{array}{l}\text { Freque- } \\
\text { ncy (\%) }\end{array}$ & $\begin{array}{l}\text { Cumu- } \\
\text { lative } \\
\text { freque- } \\
\text { ncy (\%) }\end{array}$ & & $\begin{array}{l}\text { Freque- } \\
\text { ncy }(\%)\end{array}$ & $\begin{array}{l}\text { Cumu- } \\
\text { lative } \\
\text { freque- } \\
\text { ncy }(\%)\end{array}$ & & $\begin{array}{l}\text { Freque- } \\
\text { ncy (\%) }\end{array}$ & $\begin{array}{l}\text { Cumu- } \\
\text { lative } \\
\text { freque- } \\
\text { ncy (\%) }\end{array}$ \\
\hline Aquilaspio peruana & 22.34 & 22.34 & Prionospio patagonica & 47.92 & 47.92 & Prionospio patagonica & 50.09 & 50.09 \\
\hline Carazziella carrascoi & 21.40 & 43.74 & Aquilaspio peruana & 21.32 & 69.24 & Carazziella carrascoi & 30.08 & 80.17 \\
\hline Prionospio patagonica & 19.01 & 62.75 & Rhynchospio glutaea & 9.09 & 78.33 & Dipolydora socialis & 6.46 & 86.63 \\
\hline Rhynchospio glutaea & 10.72 & 73.47 & Spiophanes sp. & 7.97 & 86.30 & Rhynchospio glutaea & 4.32 & 90.96 \\
\hline Average dissimilarity & & & & & & & & \\
\hline between groups & 85.25 & & & 95.71 & & & & 65.60 \\
\hline
\end{tabular}

TABLE 4

Total macroinfauna contribution percentages $(>65 \%)$ for similarity of the site groups (SIMPER)

Porcentajes de contribución de la macroinfauna total (> $65 \%$ ) para la similitud entre los grupos de sitios (SIMPER)

\begin{tabular}{|c|c|c|c|}
\hline Taxa & Group 1 & Group 2 & Group 3 \\
\hline Carazziella carrascoi & & 14.17 & \\
\hline Aquilaspio peruana & 12.72 & & \\
\hline Prionospio (Minuspio) patagonica & & 11.90 & 37.67 \\
\hline Rhynchospio glutaea & 3.10 & & \\
\hline Spiophanes sp. & 2.92 & & \\
\hline Capitella sp. & 9.23 & & \\
\hline Cirratulidae & 2.73 & & \\
\hline Goniada sp. & 4.76 & 6.55 & \\
\hline Haploscoloplos sp. & 3.04 & & \\
\hline Perinereis gualpensis & & 9.11 & 19.32 \\
\hline \multicolumn{4}{|l|}{ Scoloplos sp. } \\
\hline Cumacea & 6.08 & & \\
\hline \multicolumn{4}{|l|}{ Mulinia edulis } \\
\hline Nassarius gayi & 6.62 & & \\
\hline Paracorophium hartmannorum & 5.52 & 23.11 & 27.12 \\
\hline Phoxorgia sp. & 3.89 & & \\
\hline
\end{tabular}


patagonica represents a typical component of the macrofauna in estuaries at southern Chile. Aquilaspio peruana was a remarkable common species in the outer reaches of the Valdivia estuary, like it was also observed in deeper areas of Valparaiso Bay (Rozbazcylo \& Salgado 1993), and ocassionally in deep waters off the coasts of Concepción and Iquique (Oyarzún et al. 1987, Quiroga et al. 1999). This suggested that different environmental conditions and depths could affect the distribution and number of this species (Valdovinos 2001). The important contribution of Aquilaspio and Minuspio, suggests characteristics that permit the species to achieve dominance in systems, with high variability in their regimes, such as estuaries (Levin \& Huggett 1990).

The absence of significant differences in the species composition of the spionid fauna among sampling periods suggests low seasonal variability compared with the strong spatial variability in the species composition among the sampling stations. The initial low variability is probably related to stable and homogeneous conditions in the sediments in most sites, as observed during the study. Because of this, opportunistic species, similarly to those observed for other species of the family (Levin \& Huggett 1990), may be observed in environments with greater fluctuations in bottom conditions, however, they were not observed in this study.

\section{TABLE 5}

Summary of the contributions of environmental variables showing values of the Spearman rank coefficient $(\rho \mathrm{w})$ with distribution patterns of spionid community structure (BIOENV); (Sal) salinity, (S) \% sand, (Z) depth, (OM) organic matter

Resumen de la contribución de variables ambientales, mostrando valores de coeficiente de rangos de Spearman ( $\rho w)$ con los patrones de distribución de la estructura comunitaria de los espiónidos (BIOENV); (Sal) salinidad,

(S) \% arena, (Z) profundidad, $(\mathrm{OM})$ materia orgánica

\begin{tabular}{lc}
\hline Number of variables & Best variable combinations $(\rho \mathrm{w})$ \\
\hline 1 & Sal $(0.658)$ \\
2 & $\mathrm{~S}, \mathrm{Sal}(0.606)$ \\
2 & $\mathrm{Z}, \mathrm{Sal}(0.565)$ \\
3 & $\mathrm{~S}, \mathrm{Z}, \mathrm{Sal}(0.582)$ \\
3 & $\mathrm{MO}, \mathrm{Z}, \mathrm{Sal}(0.539)$ \\
\hline
\end{tabular}

The different identified assemblages allow us to establish differences in the horizontal distribution of the species, wich are probably regulated by bottom salinity, in similarly ways to the overall macrofaunal assemblage. The interior reaches of this and other estuaries in the region have greatly decreased salinities during seasons with high precipitation, compared with oceanic salinities in the outer reaches (Poblete \& Deppe 1978, Pino et al. 1994) and salinity usually is a dominant factor in the structure and distribution of estuarine macroinfauna (Holland et al. 1987, Chainho et al. 2006). Our results suggested the existence of three spionid groups across the saline gradient: marine, intermediate and estuarine, with low number of species in the group of stations located at the inner reach of the estuary, probably due to salinity stress (Sanders 1965). Teske \& Wooldridge (2003) concluded that salinity was not the only factor responsible for the presence or absence of species in these types of environments and that the nature of the sediment and its associated variables were factors of major relevance for their distribution. However, since \% of sand is an important variable for the distribution of this family, the results of this study showed that sedimentological variables were not responsible for the distribution of the polychaete fauna. Furthermore, water depth also was an important factor in the distribution of this faunistic component, which has been highlighted as important by some authors for polychaete communities associated with soft bottoms (Valdovinos 2001, RodríguezVillanueva et al. 2003). The observed sedimentological variables did not agree with the proposal of Snelgrove \& Butman (1994) on the general distribution of polychaetes. These authors suggested that organic matter content of sediment, in conjunction with the energy of the environment, were the primary factors controlling polychaete structure, while sediment particle size played a secondary role in this distribution. In the present study, the small relationship of the sedimentological characteristics with the distribution of this family can be related to the little variability of these parameters.

The organic matter of the sediment was similar in percentage to other estuaries sampled in this region (Bertrán 1984, Jaramillo et al. 
TABLE 6

Summary of variable levels which determine significant differences (SIMPROF; $r>0.60, \mathrm{P}<0.05$ ) of principal cluster groups (LINKTREE); (Sal) salinity, (S) \% sand, (OM) organic matter

Resumen de variables que determinan diferencias significativas (SIMPROF, $\mathrm{P}<0,05$ ) entre los principales grupos de cluster (LINKTREE); (Sal) salinidad, (S) \% arena, (OM) materia orgánica

\begin{tabular}{lclll}
\hline Cluster group & r-value & P-value & Variables & Levels \\
\hline A-B & 0.83 & $\mathrm{P} \leq 0.001$ & Sal & Sal, A $(>20) ; \mathrm{B}(<17)$. \\
B-C & 0.96 & $\mathrm{P} \leq 0.001$ & $\mathrm{~S}, \mathrm{OM}$ & $\mathrm{S}, \mathrm{B}(<42.8) ; \mathrm{C}(>68.5) . \mathrm{OM}, \mathrm{B}(>7.62) ; \mathrm{C}(<5.39)$. \\
C-D & 0.89 & $\mathrm{P} \leq 0.001$ & Sal & Sal, C $(>17) ; \mathrm{D}(<15)$. \\
D-E & 0.6 & $\mathrm{P} \leq 0.001$ & $\mathrm{OM}$ & $\mathrm{OM}, \mathrm{D}(<4,96) ; \mathrm{E}(>4.39)$ \\
\hline
\end{tabular}

2001) and in South America (Ieno \& Bastida 1998). Nevertheless, differences were observed among the different groups of stations, with Station 9 having greater sediment accumulation/retention and suggesting that these were areas with less dynamic and lower water movement (Valdovinos 2001). The effects of anthropogenic organic material in the sediments can not be ignored since studies have shown that species such as $C$. carrascoi can be an important faunal component in zones with high organic enrichment (Oyarzún et al. 1987, Arcos et al. 1993). The weak relation between the distribution of the spionids and sedimentary organic matter content in our study suggests that organic enrichment is not a good predictor or the spionid assemblages and that it would difficult to apply the model proposed by Pearson \& Rosenberg (1978), which relates organic matter and infaunal organization. Probably the high environmental variability of other type of factors, such as salinity, renders fluctuations in organic matter of minor importance in this system.

The important contribution of salinity in the vertical distribution of the different species of spionids suggests that these can be used as reliable indicators of the time-integrated salinity profile over estuarine bottoms in transition zones, since individual salinity measurements are not reliable and extremely variable over short time scales and they have a significant numeric participation in these ecosystems, which has been also reported by Rozbazcylo \& Salgado (1993) and Quiroga et al. (1999) for the central and northern coast of Chile, respectively, reaffirming the importance of this family as component of the benthos of South American Pacific coastal ecosystems.

\section{ACKNOWLEDGMENTS}

We thank Dr. Carlos Bemvenuti, Dr. Heraldo Contreras and Dr. Evelyn Habit for reviewing and making helpful corrections for the manuscript. We also thank Wladimir Steffen, Bárbara Cisternas, Leonora Jarpa, Francisco Bravo and Rodrigo Araya for expert help in the field.

\section{LITERATURE CITED}

ARCOS D, FURET L, CARRASCO F, NUÑES S \& F VARGAS (1993) Eutroficación en el ambiente marino de Chile central: efectos inducidos por la evacuación de residuos industriales líquidos. Investigaciones Marinas Valparaíso (Chile) 21: 51-74.

BERTRÁN C (1984) Macroinfauna intermareal en un estuario del sur de Chile (estuario del río Lingue, Valdivia). Studies on Netropical Fauna and Environment 19: 33-46.

BERTRÁN C (1989) Zonación y dinámica temporal de la macroinfauna intermareal en el estuario del río Lingue (Valdivia, Chile). Revista Chilena de Historia Natural 62: 19-32.

BERTRÁN C, ARENAS J \& O PARRA (2001) Macrofauna del curso inferior y estuario del río Biobío (Chile): cambios asociados a variabilidad estacional del caudal hídrico. Revista Chilena de Historia Natural 74: 331-340.

BEUKEMA JJ \& GC CADEÉ (1986) Zoobenthos respoonses to eutrophication of the Ductch Wadden Sea. Ophelia 26: 45-64.

BLAKE JA (1979) Four new species of Carraziella (Polychaeta:Spionidae) from North and South America,with a redescription of two previously described forms. Proceedings of the Biological Society of Washington 92: 466-481.

BLAKE JA (1983) Polychaetes of the family Spionidae from South America, Antartica and adjacent seas and islands. Biology of the Antartic Seas XIV. Antarctic Research Series 39: 205-208.

BLAKE JA (1996) Family Spionidae. In: Blake JA, Hilbig B, Scott PH (eds) Taxonomic atlas of benthic fauna of the Santa Maria basin and western Santa Barbara channel. Volume 6. Annelida Part 3. Polychaeta: 
Orbiniidae to Cossuridae: 81-223. Santa Barbara Museum of Natural History, Santa Barbara, California, USA.

BLAKE JA \& P ARNOFSKY (1999) Reproduction and larval development of the spioniform Polychaeta with application to the systematics and phylogeny. Hydrobiologia 402: 57-106.

BOLAM S \& T FERNÁNDEZ (2003) Dense aggregations of Pygospio elegans (Claparède): effect on macrofaunal community structure and sediments. Journal of Sea Research 49: 171-185.

BRAVO A (1984) Distribución de la macroinfauna submareal en los fondos blandos de la Bahía Queule y Estuario del Río Queule. Medio Ambiente (Chile) 7: $37-46$.

CAÑETE JI, HILBIG B \& M SANTANA (2004) Presence of Prionospio (Prionospio) orensanzi Blake, 1983 (Polychaeta: Spionidae) of Punta Arenas, Chile, with notes on their abundance and spatial distribution in shallow, subtidal sandy bottoms. Investigaciones Marinas de Valparaíso (Chile) 32: 121-128

CARRASCO FD (1974) Spionidae (Polychaeta) provenientes de la Bahía de Concepción y lugares adyacentes. Boletín de la Sociedad de Biología de Concepción (Chile) 48: 185-201.

CARRASCO FD (1976) Larvas de la familia Spionidae (Polychaeta) en el plancton de la Bahía de Concepción, Chile. Gayana (Chile) 38: 1-63.

CHAINHO P, COSTA JL, CHAVES ML, LANE MF, DAUER DM \& MJ COSTA (2006) Seasonal and spatial patterns of distribution of subtidal benthic invertebrate communitities in the Mondego river, Portugal a poikilohaline estuary. Hidrobiología 555: $59-74$.

CLARKE KR \& M AINSWORTH (1993) A method of linking multivariate community structure to environmental variables. Marine Ecology Progress Series 92: 205-219.

CLARKE KR \& RM WARWICK (1994) Change in marine communities. An approach to analysis and interpretation. Natural Environment Research Council, Plymouth, United Kingdom. 144 pp.

CLARKE KR \& RN GORLEY (2005) PRIMER V.6: User manual/Tutorial. Primer-E Ltda., Playmouth, United Kingdom. 190 pp.

COSTANZA R, WM KEMP \& WR BOYNTON (1993) Predictabilility, scale, and biodiversity in coastal and estuarine ecosystems: implications for management. Ambio 22: 88-96.

DAUER DM, CA MAYBURY \& MR EWING (1981) Feeding behavior and general ecology of several spionid polychaetes from the Chesapeake Bay. Journal of Experimental Marine Biology and Ecology 54: 21-38

EMERY KO (1938) Rapid method of mechanical analysis of sand. Journal of sedimentary Petrology 8: 105111.

FOLK KO (1974) Petrology of sedimentary rocks. Hemphill Publishing Co., Austin, Texas, USA. 184 $\mathrm{pp}$

GIBBS R, M MATHEWS \& D LINK (1971) The relationship between sphere size and settling velocity. Journal of sedimentary Petrology 41: 7-18.

HARTMANN O (1953) Non-pelagic Polychaeta of the Swedish Antartic Expedition 1901-1903. Zoological Results of Swedish. Antarctic Expedition 19011903 4: 1-83.

HARTMANN-SCHRÖDER G (1962) Die polychaeten des Eulitorals. In: Hartmann-Schröder G, Hartmann G (eds) Zur Kenntnis des Eulitorals der Chilenischen Pazifikküste und der Argentinischen Küste, südpatgoniens unter besonderer Berücksichtigung der Polychaeten und Ostracoden. Mitteilungen aus dem Hamburgischen Zoologischen Museum und Institut 60: 57-167.

HARTMANN-SCHRÖDER G (1965) Die polychaeten des Sublitorals. In: Hartmann-Schröder G, Hartmann G (eds) Zur Kenntnis des Sublitorals der Chilenischen kuste unter besonderer Berüchsitchtigung der Polychaeten und Ostracoden. Mitteilungen aus dem Hamburgischen Zoologischen Museum und Institut 62: 59-305

HERNÁNDEZ CE, RA MORENO \& N ROZBACZYLO (2005) Biogeographical patterns and Rapoport's rule in southeastern Pacific benthic polychaetes of the Chilean coast. Ecography 28: 363-373.

HOLLAND AF, AT SHAUGHNESS \& MH HIEGEL (1987) Long-term variation in mesohaline Chesapeake Bay macrobenthos: spatial and temporal patterns. Estuaries 10: 227-245.

IENO EN \& RO BASTIDA (1998) Spatial and temporal patterns in coastal macrobenthos of Samborom Bay, Argentina:a case of study of very low diversity. Estuaries 21: 690-699.

JARAMILLO E, S MULSOW, M PINO \& H FIGUEROA (1984) Subtidal benthic macroinfauna in an estuary of south Chile: distribution patterns in relation to type sediments. Marine Ecology 5: 119-132.

JARAMILLO E, C BERTRÁN, R AGUILAR, A TURNER \& M PINO (1985a) Annual fluctuation of the subtidal macroinfauna macroinfauna in an estuary of south of Chile. Studies on Netropical Fauna and Environment 20: 33-44.

JARAMILLO E, S MULSOW \& R NAVARRO (1985b) Intertidal and subtidal macroinfauna in the Queule river estuary, south of Chile. Revista Chilena de Historia Natural 74: 331-340.

JARAMILLO E, H CONTRERAS \& P QUIJÓN P (2001) Seasonal and interanual variability in population abundances of the intertidal macroinfauna of the Queule river estuary, south-central of Chile. Revista Chilena de Historia Natural 74: 455-468.

JOHNSON PG (1984) Family Spionidae Grube 1850. In: Uebelacker JM \& PG Jhonson (eds) Taxonomic guide to the polychaetes of the northern Gulf of Mexico: 6.1-6.9. Barry A. Vittor \& Associates, Inc., Mobile, Alabama, USA.

LANCELLOTI DA \& JA VÁSQUEZ (2000) Zoogeografía de macroinvertebrados bentónicos de la costa de Chile: contribución para la conservación marina. Revista Chilena de Historia Natural 73: 99-129.

LEVIN LA (1984) Life history and dispersal patterns in a dense infaunal polychaete assemblage: community structure and response to disturbance. Ecology 65: $1185-1200$

LEVIN LA \& DV HUGGETT (1990) Implications of alternate reproductive modes for seasonality and demography in an estuarine polychaete. Ecology 71: 2191-2208.

LOW AM (1993) Distribución y abundancia de la pequeña macroinfauna estival en tres estuarios micromareales del sur de Chile. Tesis de Biología Marina, Facultad de Ciencias, Universidad Austral de Chile, Valdivia, Chile. 52 pp.

MORENO R, R SOTO, F CARRASCO \& R SEPÚLVEDA (2002) Nuevos poliquetos de la familia Spionidae Grube, 1850 (Polycheta: Spionidae) para el norte de Chile. Noticiero Mensual del Museo Nacional de Historia Natural (Chile) 350: 9-11. 
OYARZÚN C, FD CARRASCO \& VA GALLARDO. (1987) Some characteristics of macrobenthic fauna from the organic- enriched sediments at Talcahuano, Chile. Cahiers de biologie marine 28: 429-446.

PEARSON TH \& R ROSEMBERG (1978) Macrobenthic succession in relation to organic enrichment and pollution of the marine environment. Oceanography Marine Biology Annual Review 16: 229-311.

PINO M, GM PERILLO \& P SANTAMARINA (1994) Residual fluxes in a cross section in the Valdivia River estuary, Chile. Estuarine Coastal Shelf Science 38: 491-505

POBLETE A \& J DEPPE J (1978) Distribución de los bancos de Mytilus chilensis (Bivalvia, Mytilidae) en el estuario del río Valdivia. Medio Ambiente (Chile) 3: 66-74.

QUIJÓN P \& E JARAMILLO (1993) Temporal variability in the intertidal macroinfauna in the Queule river estuary, south- central Chile. Estuarine Coastal Shelf Science 37: 655-667.

QUIJÓN P \& E JARAMILLO (1996) Seasonal vertical distribution of the intertidal macroinfauna in a estuary of south-central Chile. Estuarine Coastal Shelf Science 43: 653-663.

QUIJÓN P, E JARAMILLO \& M PINO (1996) Macroinfaunal assemblages associated with mussels clam beds in a estuary of southern Chile. Estuaries 19: 62-74.

QUIROGA E, R SOTO \& N ROZBACZYLO (1999) Los poliquetos espiónidos (Polychaeta: Spionidae) y su importancia en la estructura de una comunidad: un caso de estudio en Bahía Iquique, norte de Chile. Gayana (Chile) 63: 1-16.

RADASHEVSKY V, M DÍAZ \& C BERTRÁN (2006) Morphology and biology of Prionospio patagonica (Annelida: Spionidae) from Chile. Journal of the Marine Biological Association of the United Kingdom 86: 61-69.

RHOADS DC, JY YINGST \& WULLMAN (1978) Seafloor stability in central Long Island Sound. Temporal changes inerodability of fine-grained sediment. In: Eiley ML (ed) Estuarine interactions: 221-224. Academic Press, New York, New York, USA.

RICHTER W (1985) Distribution of the soft-bottom macroinfauna in an estuary of southern Chile. Marine Biology 86: 93-100.

RODRÍGUEZ-VILLANUEVA V, R MARTÍNEZ-LARA \& V MACÍAS (2003) Polychaete community structure of the northwestern coast of Mexico: patterns of abundante and distribution. Hidrobiologia 496: 85399.

ROZBACZYLO N \& P SALGADO (1993) Poliquetos Spionidae de fondos blandos submareales de la Bahía de Valparaíso, Chile (Annelida: Polychaeta). Estudios. Oceanológicos (Chile) 12: 17-28.

SANDERS HL, PC MANGELSDORF \& GR HAMPSON (1965) Salinity and faunal distribution in the Pocasset river, Massachusetts. Limnology and Oceanography 10: 216-219.

SATO-OKOSHI W \& M TAKATSUKA (2001) Polydora and related genera (Polychaeta, Spionidae) around Puerto Montt and Chiloé Island (Chile), with description of a new species of Dipolydora. Bulletin of Marine Science 68: 485-503.

SNELGROVE P \& CA BUTMAN (1994) Animalsediment relationships revisited: cause versus effect. Oceanography and Marine Biology: an Annual Review 32: 111-177.

SOKAL R \& F ROHLF (1995) Biometry. W.H. Freeman and Company, New York, New York, USA. 877 pp.

TESKE PR \& TH WOOLDRIGDE (2003) Whats limits the distribution of subtidal macrobenthos in permanently open and temporarily open/closed estuary South Afican estuaries? Salinity vs. sediment particle size. Estuarine, Coastal and Shelf Science 57: 225-238.

TURNER A (1984) Zonación y estratificación de la macroinfauna intermareal del estuario del río Queule (IX Región, Chile). Medio Ambiente (Chile) 7: 29-36

VALDOVINOS C (2001) Biodiversidad de los fondos blandos sublitorales: macroinvertebrados del Golfo de Arauco (Chile). In: Alveal K \& T Antezana (eds) Sustentabilidad de la biodiversidad: 635-662. Ediciones de la Universidad de Concepción, Concepción, Chile.

WHITLATCH RB \& R ZAJAC (1985) Biotic interactions among estuarine opportunists. Marine Ecology Progress Series 21: 299-311. 